DOI: $10.15193 /$ zntj/2017/112/197

\author{
MAGDALENA GAJEWSKA, ANNA GŁOWACKA
}

\title{
OCENA ZANIECZYSZCZENIA GRZYBAMI PLEŚNIOWYMI SUSZONYCH ZIÓL I PRZYPRAW DOSTĘPNYCH W SKLEPACH EKOLOGICZNYCH I HIPERMARKETACH
}

\begin{abstract}
Streszczenie
Celem pracy było określenie poziomu zanieczyszczenia grzybami strzępkowymi suszonych ziół oraz przypraw dostępnych w sprzedaży detalicznej w sklepach ekologicznych i hipermarketach województwa łódzkiego. Badaniami objęto 13 rodzajów produktów: czosnek (Allium sativum), koper (Anethum graveolens), natkę pietruszki (Petroselinum crispum), bazylię (Ocimum basilicum), oregano (Origanum vulgare), estragon (Artemisia dracunculus), tymianek (Thymus vulgaris), majeranek (Origanum majorana), gałkę muszkatołową (Myristica fragans), curry (Helichrysum angustifolia), kurkumę (Curcuma longa), pieprz czarny (Piper nigrum), paprykę słodką (Capsicum annuum). Analiza mikrobiologiczna obejmowała oznaczenie liczby grzybów pleśniowych i ich skład jakościowy. Zanieczyszczenie badanych ziół oraz przypraw przez grzyby strzępkowe było zróżnicowane i nie przekraczało poziomu $10^{4} \mathrm{jtk} \cdot \mathrm{g}^{-1}$.W czterech produktach: bazylii, curry, kurkumie i papryce słodkiej próbki zakupione w hipermarkecie charakteryzowały się istotnie większym zanieczyszczeniem przez pleśnie w porównaniu z próbkami pochodzącymi ze sklepu ekologicznego. Wykazano brak zróżnicowania poziomu zanieczyszczenia grzybami strzępkowymi badanych produktów w zależności od miejsca zakupu. Średnia liczba pleśni w ziołach i przyprawach zakupionych w sklepach ekologicznych oraz w produktach pochodzących z hipermarketu kształtowała się na podobnym poziomie. Stwierdzono natomiast zróżnicowanie poziomu zanieczyszczenia pleśniami w zależności od rodzaju przyprawy. Wyizolowane z suszonych ziół oraz przypraw grzyby strzępkowe należały łącznie do 5 rodzajów. Zidentyfikowano pleśnie z rodzaju Aspergillus (A. niger, A. flavus), Penicillium, Mucor, Alternaria i Cladosporium.
\end{abstract}

Słowa kluczowe: suszone zioła, przyprawy, zanieczyszczenie mikrobiologiczne, grzyby pleśniowe

Mgr inż. M. Gajewska, Zakład Jakości Żywności, ul. Marszałka J. Pitsudskiego 84, 92-202 Łódź, Instytut Biotechnologii Przemystu Rolno-Spożywczego im. prof. Wacława Dąbrowskiego, ul. Rakowiecka 36, 02-532 Warszawa, dr hab. n. med. A. Glowacka, prof. nadzw, Katedra Nauk Podstawowych, Wydz. Wojskowo-Lekarski, Uniwersytet Medyczny w Łodzi, ul. Żeligowskiego 7/9, 90-647 Łódź.

Kontakt: magdalena.gajewska@ibprs.pl 


\section{Wprowadzenie}

Rośliny przyprawowe oraz przyprawy zwiększają walory sensoryczne żywności, poprawiają smak i zapach potraw, a także zwiększają ich wartość odżywczą oraz trwałość. Są powszechnie stosowane w przemyśle spożywczym, gastronomii oraz w gospodarstwach domowych nie tylko z uwagi na niepowtarzalny smak i aromat, ale także ze względu na obecność w ich składzie związków biologicznie aktywnych [1].

Konsument zainteresowany jest nie tylko wartością odżywczą nabywanych produktów spożywczych, lecz również ich bezpieczeństwem zdrowotnym. W ostatnich latach znacząco wzrosło zainteresowanie składnikami biologicznie aktywnymi, w tym przeciwutleniaczami, występującymi w roślinach $\mathrm{z}$ uwagi na ich korzystny wpływ na zdrowie człowieka $[1,4,14,15]$ i ważną rolę w prewencji tzw. chorób cywilizacyjnych $[11,17,19]$. Wyniki prowadzonych badań potwierdzają, że zioła i przyprawy stanowią bogate źródło naturalnych związków o właściwościach przeciwutleniających. Niemniej jednak, podobnie jak wiele innych płodów rolnych, zioła i przyprawy są narażone na różnego rodzaju zanieczyszczenia mikrobiologiczne, które w znacznym stopniu zależą od warunków środowiska. Zanieczyszczenie może nastąpić na każdym etapie produkcji, czyli podczas uprawy, jak i w czasie zbioru, obróbki, przechowywania i transportu [20].

Wyniki badań związanych z oceną mikrobiologiczną surowców roślinnych wykazują, że spośród czynników biologicznych znaczny stopień zanieczyszczenia tych produktów stanowi mikroflora należąca do grzybów strzępkowych, potocznie zwanych pleśniami. Pleśnie, poza niekorzystnymi zmianami w samym produkcie, są także niebezpieczne dla człowieka. Wywołują alergie, a ich wtórne metabolity - mikotoksyny mogą być przyczyną ostrych zatruć. Związki te powodują u ludzi i zwierząt efekty toksyczności o charakterze ostrym, podostrym lub przewlekłym, wykazują także działanie kancerogenne, teratogenne, genotoksyczne, immunotoksyczne i neurotoksyczne $[8,16]$. W poszukiwaniu alternatywnych metod upraw, eliminujących gromadzenie się w płodach rolnych różnych zanieczyszczeń, zwrócono uwagę na rolnictwo ekologiczne. $\mathrm{Z}$ danych literaturowych wynika, że produkty z upraw ekologicznych charakteryzuje wysoka jakość odżywcza i zdrowotna [14]. Ostatnio pojawiają się jednak wątpliwości, czy żywność pozyskiwana metodami ekologicznymi rzeczywiście odznacza się mniejszą zawartością zanieczyszczeń, a większą zawartością bioaktywnych substancji prozdrowotnych [15].

Celem pracy było określenie poziomu zanieczyszczenia grzybami strzępkowymi suszonych ziół oraz przypraw dostępnych w sklepach ekologicznych i hipermarketach województwa łódzkiego. 


\section{Material i metody badań}

Materiał do badań stanowiły wybrane rodzaje suszonych ziół oraz przypraw: czosnek (Allium sativum), koper (Anethum graveolens), natka pietruszki (Petroselinum crispum), bazylia (Ocimum basilicum), oregano (Origanum vulgare), estragon (Artemisia dracunculus), tymianek (Thymus vulgaris), majeranek (Origanum majorana), gałka muszkatołowa (Myristica fragans), curry (Helichrysum angustifolia), kurkuma (Curcuma longa), pieprz czarny (Piper nigrum), papryka słodka (Capsicum annuum). Próbki zakupiono w sklepach z produktami ekologicznymi (4 sklepy) oraz w hipermarketach (4 sieci handlowe) w obrębie województwa łódzkiego. W obydwu typach sklepów wybrano po 4 różne marki każdego rodzaju produktu.

Analiza mikrobiologiczna obejmowała oznaczenie liczby grzybów pleśniowych i ich skład jakościowy. Liczbę grzybów strzępkowych określano metodą płytkową poprzez posiew wgłębny na podłoże Sabourauda z chloramfenikolem i inkubację w temp. $25^{\circ} \mathrm{C}$ do 5 dni według PN-ISO 21527-1:2009 [10]. Na podstawie cech makroi mikroskopowych grzybni prowadzono ocenę składu jakościowego grzybów pleśniowych z użyciem atlasów: „Atlas grzybów chorobotwórczych człowieka” [7] oraz „Atlas of clinical fungi” [6].

Posiew każdej próbki ziół i przypraw przeprowadzono w trzech powtórzeniach. Liczbę grzybów pleśniowych wyrażano jako jednostki tworzące kolonie w $1 \mathrm{~g}\left(\mathrm{jtk} \cdot \mathrm{g}^{-1}\right)$ i transponowano je do postaci logarytmicznej w celu wykonania analizy statystycznej. Wyniki badań poddano testom nieparametrycznym przy użyciu programu komputerowego Statistica 10. Za pomocą testu Manna-Whitneya obliczano istotność różnic ( $\mathrm{p}=$ $0,05)$ między średnią liczbą grzybów pleśniowych w poszczególnych rodzajach suszonych ziół i przypraw zakupionych w sklepach ekologicznych i hipermarketach. Przy użyciu testu Kruskala-Wallisa dokonano oceny zróżnicowania poziomu zanieczyszczenia grzybami strzępkowymi badanych produktów w zależności od rodzaju przyprawy oraz miejsca zakupu.

\section{Wyniki i dyskusja}

Wyniki oceny zanieczyszczenia grzybami pleśniowymi wybranych ziół i przypraw zamieszczono w tab. 1.

Zanieczyszczenie badanych ziół oraz przypraw przez grzyby strzępkowe było zróżnicowane i nie przekraczało poziomu $10^{4} \mathrm{jtk} \cdot \mathrm{g}^{-1}\left(4,89 \mathrm{log} \mathrm{jtk} \cdot \mathrm{g}^{-1}\right)$. Najmniejszą liczbę pleśni stwierdzono w czosnku, w większości próbek były one nieobecne bądź występowały nielicznie $-1,18 \mathrm{log} \mathrm{jtk} \cdot \mathrm{g}^{-1}\left(15 \mathrm{jtk} \cdot \mathrm{g}^{-1}\right)$. Największe zanieczyszczenie grzybami pleśniowymi występowało $\mathrm{w}$ próbce papryki słodkiej zakupionej w hipermarkecie $-7,8 \cdot 104 \mathrm{jtk} \cdot \mathrm{g}^{-1}\left(4,89 \mathrm{log} \mathrm{jtk} \cdot \mathrm{g}^{-1}\right)$. Stwierdzono istotnie wyższe zanieczyszczenie pleśniami w bazylii, curry, kurkumie i w papryce słodkiej zakupionych w hi- 
permarkecie $\mathrm{w}$ porównaniu $\mathrm{z}$ próbkami pochodzącymi ze sklepu ekologicznego. W pozostałych rodzajach ziół i przypraw różnice te były nieistotne.

Tabela 1. Liczba grzybów strzępkowych w suszonych ziołach i przyprawach w zależności od miejsca zakupu

Table 1. Total count of moulds isolated from dried herbs and spices depending on the place of purchase

\begin{tabular}{|c|c|c|c|c|c|}
\hline \multirow{3}{*}{$\begin{array}{l}\text { Zioła / Przyprawy } \\
\text { Herbs / Spices }\end{array}$} & \multicolumn{4}{|c|}{$\begin{array}{c}\text { Liczba grzybów strzępkowych }\left[\log \mathrm{jtk}_{\mathrm{g}} \mathrm{g}^{-1}\right] \\
\text { Count of moulds }\left[\log \mathrm{cfu} \cdot \mathrm{g}^{-1}\right]\end{array}$} & \multirow{3}{*}{$\begin{array}{c}\begin{array}{c}\text { Istotność } \\
\text { różnic } \\
\text { Significance } \\
\text { of differences }\end{array} \\
\mathrm{p}\end{array}$} \\
\hline & \multicolumn{2}{|c|}{$\begin{array}{c}\text { Sklep ekologiczny } \\
\text { Organic store } \\
(\mathrm{n}=52)\end{array}$} & \multicolumn{2}{|c|}{$\begin{array}{c}\text { Hipermarket } \\
\text { Hypermarket } \\
(\mathrm{n}=52)\end{array}$} & \\
\hline & $\begin{array}{l}\text { Zakres } \\
\text { Range }\end{array}$ & $\overline{\mathrm{x}}$ & $\begin{array}{l}\text { Zakres } \\
\text { Range }\end{array}$ & $\overline{\mathrm{x}}$ & \\
\hline $\begin{array}{l}\text { Czosnek mielony } \\
\text { Garlic powder } \\
\end{array}$ & $\mathrm{nb}$ & - & $\mathrm{nb} \div 1,18$ & - & - \\
\hline Koper / Dill & $3,80 \div 4,34$ & 4,13 & $2,30 \div 4,36$ & 3,87 & 0,543 \\
\hline $\begin{array}{l}\text { Natka pietruszki } \\
\text { Parsley }\end{array}$ & $2,00 \div 4,41$ & 3,21 & $2,30 \div 4,30$ & 3,20 & 1,000 \\
\hline Bazylia / Basil & $2,78 \div 3,95$ & 3,36 & $3,70 \div 4,71$ & 4,14 & 0,031 \\
\hline Oregano / Oregano & $4,40 \div 4,46$ & 4,44 & $3,90 \div 4,62$ & 4,61 & 0,684 \\
\hline Estragon / Tarragon & $2,48 \div 4,46$ & 3,47 & $3,36 \div 4,30$ & 3,64 & 0,682 \\
\hline Tymianek / Thyme & $2,30 \div 3,62$ & 2,96 & $2,00 \div 3,32$ & 2,77 & 0,621 \\
\hline Majeranek / Marjoram & $3,00 \div 3,40$ & 3,17 & $3,30 \div 3,61$ & 3,45 & 0,530 \\
\hline $\begin{array}{l}\text { Gałka muszkatołowa } \\
\text { Nutmeg }\end{array}$ & $3,32 \div 4,04$ & 3,68 & $2,40 \div 4,49$ & 3,67 & 1,000 \\
\hline Curry / Curry & $3,20 \div 3,41$ & 3,36 & $3,48 \div 4,57$ & 4,17 & 0,028 \\
\hline Kurkuma / Turmeric & $2,50 \div 2,91$ & 2,72 & $3,62 \div 3,80$ & 3,73 & 0,027 \\
\hline $\begin{array}{l}\text { Pieprz czarny mielony } \\
\text { Black pepper powder }\end{array}$ & $3,48 \div 3,65$ & 3,55 & $3,45 \div 3,80$ & 3,63 & 0,661 \\
\hline $\begin{array}{l}\text { Papryka słodka mielona } \\
\text { Sweet paprika powder }\end{array}$ & $2,60 \div 2,88$ & 2,74 & $3,71 \div 4,89$ & 4,29 & 0,028 \\
\hline$\overline{\mathrm{x}}$ & - & 3,14 & - & 3,51 & 0,542 \\
\hline
\end{tabular}

Objaśnienia / Explanatory notes:

$\overline{\mathrm{X}}$ - wartość średnia / mean value; $\mathrm{n}$ - liczba próbek / number of samples; $\mathrm{nb}$ - nieobecne w $1 \mathrm{~g}$ / absent in $1 \mathrm{~g}$.

Ponadto wykazano brak zróżnicowania poziomu zanieczyszczenia grzybami strzępkowymi badanych produktów w zależności od miejsca zakupu $(\mathrm{p}=0,054)$. Średnia liczba pleśni w ziołach i przyprawach zakupionych w sklepach ekologicznych oraz w produktach pochodzących $\mathrm{z}$ hipermarketu kształtowała się na podobnym poziomie (wynosiła ona odpowiednio $\left[\log \mathrm{jtk}_{\mathrm{g}}{ }^{-1}\right]$ : 3,14 oraz 3,51 ). Można zatem przypuszczać, 
że przyczyną zanieczyszczenia grzybami strzępkowymi badanego materiału są nieodpowiednie warunki przechowywania. Stwierdzono natomiast zróżnicowanie poziomu zanieczyszczenia pleśniami w zależności od rodzaju przyprawy (rys. 1).

Istotne różnice pod względem liczby grzybów strzępkowych wykazano pomiędzy: czosnkiem i pozostałymi przyprawami $(\mathrm{p}<0,0001)$, oregano i tymiankiem $(\mathrm{p}=$ $0,0042)$, oregano i majerankiem $(\mathrm{p}=0,044)$ oraz oregano i pieprzem czarnym $(\mathrm{p}=$ $0,046)$.

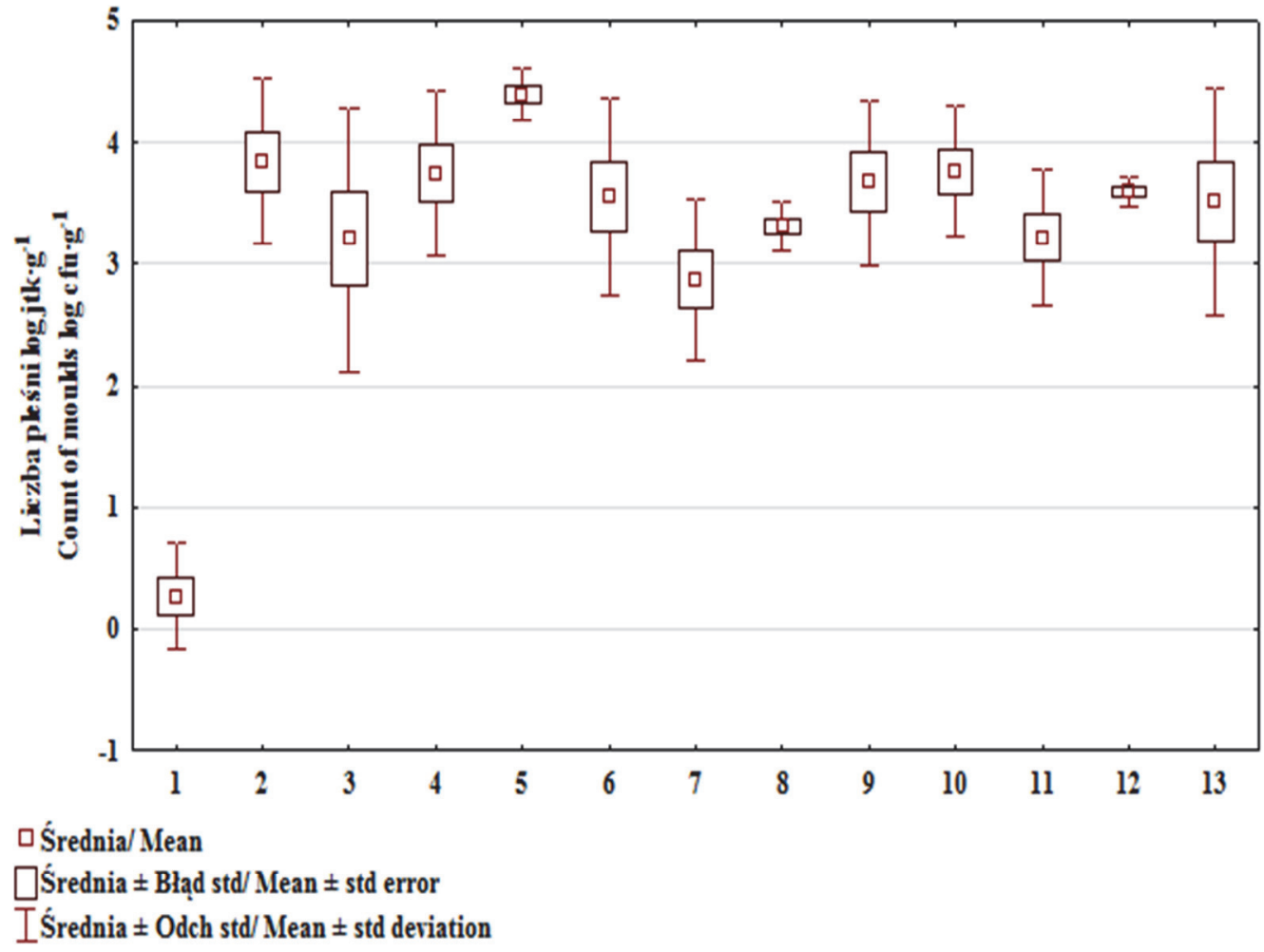

Objaśnienia / Explanatory notes:

1 - czosnek / garlic, 2 - koper / dill, 3 - pietruszka / parsley, 4 - bazylia / basil, 5 - oregano / oregano, 6 estragon / tarragon, 7 - tymianek / thyme, 8 - majeranek / marjoram, 9 - gałka muszkatołowa / nutmeg, 10 - curry / curry, 11 - kurkuma / turmeric, 12 - pieprz czarny mielony / black pepper powder, 13 - papryka słodka mielona / sweet paprika powder

Rys. 1. Średnie rangi liczby pleśni log $\mathrm{jtk} \cdot \mathrm{g}^{-1} \mathrm{~W}$ poszczególnych rodzajach przypraw

Fig. 1. Mean ranks of counts of moulds $\log \mathrm{cfu} \cdot \mathrm{g}^{-1}$ in different spices

Jakość mikrobiologiczna przypraw, zarówno pod względem liczby, jak i rodzaju występujących w nich drobnoustrojów, jest zróżnicowana [12]. Według danych litera- 
turowych liczba pleśni w suszach roślin przyprawowych i przyprawach kształtuje się na poziomie od 0 do $10^{6} \mathrm{jtk} \cdot \mathrm{g}^{-1}$, a do najbardziej zanieczyszczonych należą: pieprz czarny, majeranek, kminek, papryka, bazylia i cynamon [18]. Uzyskane w niniejszej pracy wyniki badań, dotyczące poziomu zanieczyszczenia przez pleśnie suszonych ziół i przypraw, są porównywalne z wynikami uzyskanymi przez innych autorów $[2,9,12$, 19].

W tab. 2. przedstawiono wyniki oceny składu jakościowego grzybów pleśniowych wyizolowanych z ocenianych ziół i przypraw.

Pleśnie obecne w badanych produktach należały łącznie do 5 rodzajów. Najliczniej reprezentowany był rodzaj Aspergillus, a dominującym gatunkiem był A. niger, którego obecność stwierdzono we wszystkich rodzajach ziół i przypraw - średni udział w ogólnej liczbie wyizolowanych szczepów wynosił 52,3 \% w produktach zakupionych w sklepach ekologicznych oraz $54,7 \% \mathrm{w}$ produktach pochodzących z hipermarketów. Bardzo licznie występował także A. flavus - średni udział wynosił odpowiednio: 46,2 i 36,5 \%, z mniejszą częstotliwością - Penicillium sp. (odpowiednio: 22,0 i 17,4 \%) oraz Mucor sp. (28,8 i 10,2 \%), następnie Alternaria sp. (18,1 i 13,5 \%) i pojedynczo Cladosporium sp. (6 \% w próbce bazylii zakupionej w hipermarkecie). Wyizolowane z badanych ziół oraz przypraw grzyby strzępkowe to mikroflora typowa dla tego typu produktów. Uzyskane wyniki własne są potwierdzeniem danych literaturowych, że Aspergillus sp. i Penicillium sp. stanowią główne zanieczyszczenie ziół i przypraw. Wójcik-Stopczyńska i wsp. [20] w suszonych ziołach przyprawowych zidentyfikowali pleśnie z rodzaju Aspergillus, Penicillium, Mucor, Rhizopus, Alternaria oraz Cladosporium. Stwierdzili także, że dominującymi gatunkami są Aspergillus i Penicillium. Podobne wyniki uzyskali Elshafie i wsp. [3], Hammami i wsp. [5], Mandeel [9], Wieczorkiewicz-Górnik i wsp. [18] oraz Rizzo i wsp. [13]. Ponadto Bugno i wsp [2] wykazali, że w suszonych ziołach, oprócz dominujących pleśni z rodzajów Aspergillus i Penicillium, obecne były także grzyby pleśniowe występujące w mikroflorze świeżych ziół ocenianych przez Wójcik-Stopczyńską i wsp. [19]: Cladosporium sp., Alternaria sp., Mucor sp., Rhizopus sp. Zanieczyszczenie pleśniami z rodzaju Aspergillus i Penicillium jest niepokojące pod względem mikotoksykologicznym z uwagi na możliwość zanieczyszczenia suszonych ziół i przypraw mikotoksynami. 


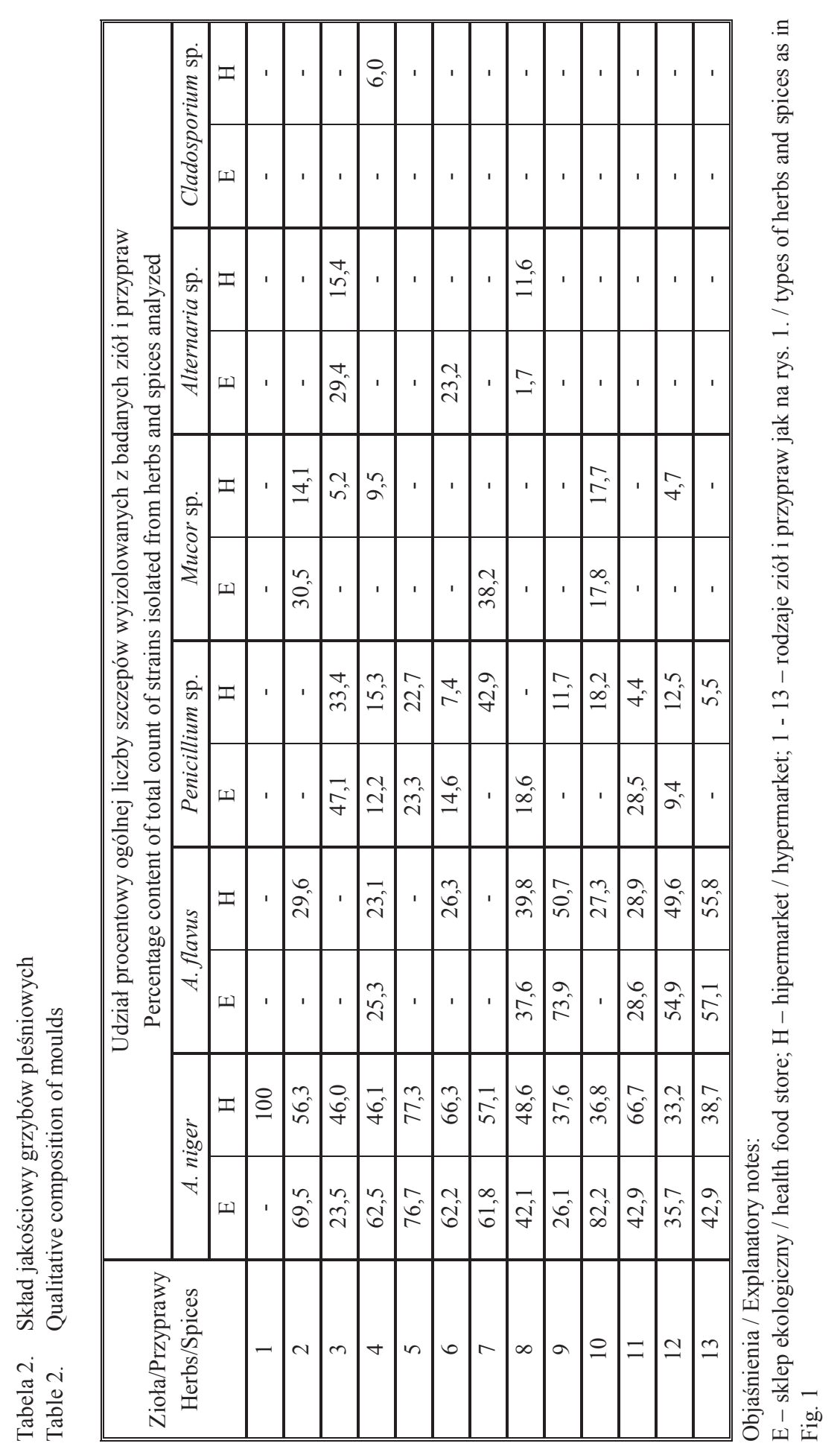




\section{Wnioski}

1. Zanieczyszczenie badanych ziół oraz przypraw przez grzyby strzępkowe było zróżnicowane i nie przekraczało poziomu $10^{4} \mathrm{jtk} \cdot \mathrm{g}^{-1}\left(4,89 \mathrm{log} \mathrm{jtk} \cdot \mathrm{g}^{-1}\right)$.

2. Cztery produkty zakupione w hipermarkecie: bazylia, curry, kurkuma i papryka słodka charakteryzowały się istotnie większym zanieczyszczeniem przez pleśnie, w porównaniu z próbkami pochodzącymi ze sklepu ekologicznego.

3. Wykazano brak zróżnicowania poziomu zanieczyszczenia grzybami strzępkowymi badanych produktów w zależności od miejsca zakupu. Średnia liczba pleśni w ziołach i przyprawach zakupionych w sklepach ekologicznych oraz w produktach pochodzących z hipermarketu kształtowała się na podobnym poziomie.

4. Stwierdzono zróżnicowanie poziomu zanieczyszczenia pleśniami w zależności od rodzaju przyprawy.

5. Wyizolowane $\mathrm{z}$ suszonych ziół oraz przypraw grzyby strzępkowe to mikroflora typowa dla tego rodzaju produktów. Zidentyfikowano pleśnie z rodzaju Aspergillus (A. niger, A. flavus), Penicillium, Mucor, Alternaria i Cladosporium.

\section{Literatura}

[1] Bieżanowska-Kopeć R., Leszczyńska T., Pysz M.: Preferencje i częstotliwość stosowania roślin przyprawowych przez mieszkańców województwa małopolskiego - badania pilotażowe. Bromat. Chem. Toksykol., 2014, XLVII (3), 277-283.

[2] Bugno A., Almodovar A., Pereira T., Pinto T., Sabino M.: Occurrence of toxigenic fungi in herbal drugs. Brazilian J. Microbiol., 2006, 37, 47-51.

[3] Elshafie A.E., Al-Rashdi T., Al-Bahry S.N., Bakheit Ch.S.: Fungi and aflatoxins associated with spices in Sultanate of Oman. Mycopathologia, 2002, 155 (3), 155-160.

[4] Grzeszczuk M., Jadczak D.: Estimation of biological value and suitability for freezing of some species of Spice herbs. J. Elem., 2008, 13 (2), 211-220.

[5] Hammami W., Fiori S., Al Thani R., Ali Kali N., Balmas V., Migheli Q., Jaoua S.: Fungal and aflatoxin contamination of marketed spices. Food Control, 2014, 37, 177-181.

[6] De Hoog G.S., Guarro J., Gene J., Figueras M.J.: Atlas of Clinical Fungi. $2^{\text {nd }}$ ed. ASM Press, Centraalbureau voor Schimmelcultures, Utrecht, The Netherlands, 2001.

[7] Krzyściak P., Skóra M., Macura A.B.: Atlas grzybów chorobotwórczych człowieka. MedPharm, Wrocław 2011.

[8] Ledzion E., Rybińska K., Postupolski J., Kurpińska-Jaworska J., Szczęsna M.: Badania i ocena bezpieczeństwa surowców zielarskich w zakresie zanieczyszczenia aflatoksynami. Roczn. PZH, 2011, 62, 4, 377-381.

[9] Mandeel Q.A.: Fungal contamination of some imported spices. Mycopathologia, 2005, 159 (2), 291298.

[10] PN-ISO 21527-1:2009. Mikrobiologia żywności i pasz. Horyzontalna metoda oznaczania liczby drożdży i pleśni. Część 1: Metoda liczenia kolonii w produktach o aktywności wody wyższej niż 0,95 .

[11] Pszczoła D.E.: A spice odyssey. Food Technol., 2001, 55, 1, 36-44. 
[12] Remiszewski M., Kulczak M., Jeżewska M., Korbas E., Czajkowska D.: Wpływ procesu dekontaminacji z zastosowaniem pary wodnej na jakość wybranych przypraw. Żywność. Nauka. Technologia. Jakość, 2006, 3 (48), 23-34.

[13] Rizzo I., Vedoya G., Maurutto S., Haidukowski M., Varsavsky E.: Assessment of toxigenic fungi on Argentinean medicinal herbs. Microbiol. Res., 2004, 159 (2), 113-120.

[14] Seidler-Łożykowska K., Golcz A., Wójcik J.: Yield and quality of sweet basil, savory, marjoram and thyme raw materials from organic cultivation on the composted manure. J. Res. Appl. Agric. Eng. 2008, 53 (4), 63-66.

[15] Seidler-Łożykowska K., Kozik E., Golcz A., Wójcik J.: Quality of basil herb (Ocimum basilicum L.) from organic and conventional cultivation. Herba Pol., 2007, 53 (3), 41-46.

[16] Steinka I., Misiewicz Ł., Kukułowicz A., Ćwikliński M., Dmowski P., Sznajdrowska A.: Próba oceny jakości mikrobiologicznej wybranych suszy roślinnych stosowanych jako używki i preparaty o znaczeniu leczniczym. Zesz. Nauk. Akademii Morskiej w Gdyni, 2011, 68, 13-20.

[17] Szajdek A., Borowska J.: Właściwości przeciwutleniające żywności pochodzenia roślinnego. Żywność. Nauka. Technologia. Jakość, 2004, 4 (41) Supl., 5-28.

[18] Wieczorkiewicz-Górnik M., Piątkiewicz A.: Mikrobiologiczne zanieczyszczenia przypraw ziołowych. Gospodarka Mięsna, 2001, 8, 46-49.

[19] Wójcik-Stopczyńska B., Jakowienko P., Jadczak D.: Ocena mikrobiologicznego zanieczyszczenia świeżej bazylii i mięty. Żywność. Nauka. Technologia. Jakość, 2010, 4 (71), 122-131.

[20] Wójcik-Stopczyńska B., Jakubowska B., Reichelt M.: Microbiological contamination of dried culinary herbs. Herba Pol., 2009, 55 (3), 206-213.

\title{
ASSESSING FILAMENTOUS FUNGAL CONTAMINATION OF DRIED HERBS AND SPICES AVAILABLE IN RETAIL HEALTH FOOD STORES AND HYPERMARKETS
}

\author{
$\mathrm{S}$ u m m a r y
}

The objective of this paper was to determine the filamentous fungi contamination of dried herbs and spices available in retail health food stores and hypermarkets in the Province of Łódź. The research material covered 13 types of products: garlic (Allium sativum), dill (Anethum graveolens), parsley (Petroselinum crispum), basil (Ocimum basilicum), oregano (Origanum vulgare), tarragon (Artemisia dracunculus), thyme (Thymus vulgaris), marjoram (Origanum majorana), nutmeg (Myristica fragans), curry (Helichrysum angustifolia), turmeric (Curcuma longa), black pepper (Piper nigrum), and sweet paprika (Capsicum annuиm). The microbiological analysis performed included the determination of the count of filamentous fungi and their qualitative composition. The filamentous fungal contamination of the tested herbs and spices varied and did not exceed $10^{4} \mathrm{cfu} \cdot \mathrm{g}^{-1}$. In the four products: basil, curry, turmeric and sweet paprika, the samples, bought in the hypermarket, were characterized by a significantly higher mould contamination compared to the samples purchased in the health food store. No differences were found between the levels of filamentous fungal contamination of the products tested depending on the place of purchase. The average load of moulds in the herbs and spices bought in the health food stores and in the products from the hypermarket was at a similar level. Though, the level of mould contamination differed depending on the type of spice. The filamentous fungi isolated from the dried herbs and spices were represented by 5 genera: Aspergillus (A. niger, A. flavus), Penicillium, Mucor, Alternaria and Cladosporium.

Key words: dried herbs, spices, microbiological contamination, filamentous fungi 